\title{
Analysis Relates to the Causes of Damage on the OOG Elevator through Failure Mode Effect Analysis Method
}

\author{
Fauzi Akbar, Rosalendro Eddy Nugroho
}

\begin{abstract}
This research has a purpose to investigate the causes of damage to the OOG elevator at Terminal 3 of Soekarno-Hatta Airport. The research data was the report data from unit damage data from January 2019 to December 2019. The analysis method used in this research was failure mode and effect analysis (FMEA), fishbone diagram analysis and why-why analysis. The results from this research show that during one year period there was 49 damage from 16 elevator units in the domestic area of Terminal 3 at Soekarno-Hatta Airport. The damage data was taken by 3 unit samples as a comparison to the OOG elevator, by each number of damage was; OOG elevators 26 times, elevator plaza 8 times and elevator loading dock 6 times, from the types of damage classified through the FMEA method, it was found that the one who caused this with the highest risk priority number (RPN) of 200 was caused by human error because the car door was hit by a pallet trolly. And this data was re-analyzed through fishbone diagrams and why-why analysis to get suggestions and recommendations as for improvements to the company in order to reduce the amount of damage which occurs on the elevator unit.
\end{abstract}

Index Terms-FMEA, the highest risks priority number (RPN), causes of damage, fishbone diagram, why-why analysis.

\section{INTRODUCTION}

The OOG elevator is one of the indoor transportation support facilities at the airport, especially at Soekarno-Hatta International Airport at Terminal 3. The role of the OOG elevator is very important because all the passenger goods which are categorized as OOG before being transported to the airplane should go through this OOG elevator, so if the OOG elevator was damaged, there is a potential for delays in passenger goods and sometimes even missed the flight and would have an impact on complaints from passengers which arrive at Airport.

According to the reports of damage in the domestic area elevator at terminal 3 of Soekarno-Hatta Airport from January 2019 until December 2019, it said that the OOG elevator has experienced the highest number of damage compared to others. Based on this data, it is known that there are 3 out of 16 elevator units with the highest number of

Fauzi Akbar, Student of Postgraduate, Universitas Mercu Buana, Jakarta, Indonesia

Rosalendro Eddy Nugroho, Lecturer of Postgraduate, Universitas Mercu Buana, Jakarta, Indonesia. damage, namely, the OOG elevator with 26 damage and the elevator plaza with 8 damage, then also the elevator loading dock with 6 times damaged. While the number of categories of damage were divided as the heavy category is 5 times of the damage, the moderate damage category is 20 times and the light category is 24 times, then the type of damage caused by human error is 17 times, mechanical electrical damage is 16 times, electrical damage is 8 times and mechanical is 8 times also for the downtime on the entire elevator is around 1,904 minutes, so as its written from the existing data sources then the author will look for the cause or root of the problem which causes the damage that often occurs in the OOG elevator.

According to this phenomenon, the author wants to find out more about the factors which cause the damage to the OOG elevator, as well as proposals for companies to repair in order to reduce the level of damage on the OOG elevator.

\section{THEORETICAL REVIEW}

\section{A. Elevator}

An elevator is a tool for lifting and lowering loads between floors in a multi-story building or could be said more than one floor building. Commonly, the types of elevators/lifts could be seen from the use of cargo and could be classified into 3 (three) groups, namely passenger elevators, freight elevators and dumb waiters. The main components of the elevator are the machine room and hoistway (Susman, 2012).

\section{B. Failure Mode and Effect Analysis (FMEA)}

Taken from Moubray (1997), the Failure mode and effect analysis is a method that is used to identify the form of failure which might cause any malfunction and also to assure the effect of failure is related to each form of failure. Meanwhile, Leitch (1983) defines the FMEA as a technical analysis if its done correctly and accordingly, it would provide a great value in creating the decision-making process of engineers during design and development. The purpose of FMEA is to develop, increase and control the probability value or price of failure detected from the source (input) and also to reduce the effects which are caused by the failure event (Novyanto, 2007).

\section{Fishbone Diagram}

Fishbone diagrams are graphic techniques for demonstrated some of the causes of a particular event or phenomenon. Based on Goetsch in Ridwansyah et al. (2019) fishbone diagrams are used to determine and classify the causes of problems. This diagram is usually arranged based on information which is earned by Conceived or 
brainstorming (Alamsyah, 2015). Furthermore, Murnawan \& Mustofa (2014) in his research found that the fishbone diagrams would provide many advantages for the business world, such as solving quality problems which are an important concern and those other classic problems.

\section{Previous Research}

Pratama \& Rahardjo (2020) who found that the main factor in the supervision and selection of sub-contractors on the placing/installation process is very influential to the installation defects of the lift. Meanwhile, Adi (2020) found that through this fishbone diagram could be revealed the cause of the defect and then prevent it with the FMEA method, so it is expected to decrease the defects in the future.

Rusmiati (2012) found that the FRPN estimation through the fuzzy FMEA method is more consistent than the conventional one, because the fuzzy FMEA could be seen the details in which types of failures are priority. Meanwhile, Nurkertamanda \& Wulandari (2009) found that through the failure mode analysis, it is expected that the quality of the product will increase and could be used according to its function. The RPN is a critical indicator to reveal the corrective action based on the failure mode.

\section{E. Theoretical Framework}

The theoretical framework from this research is could be seen as follows:

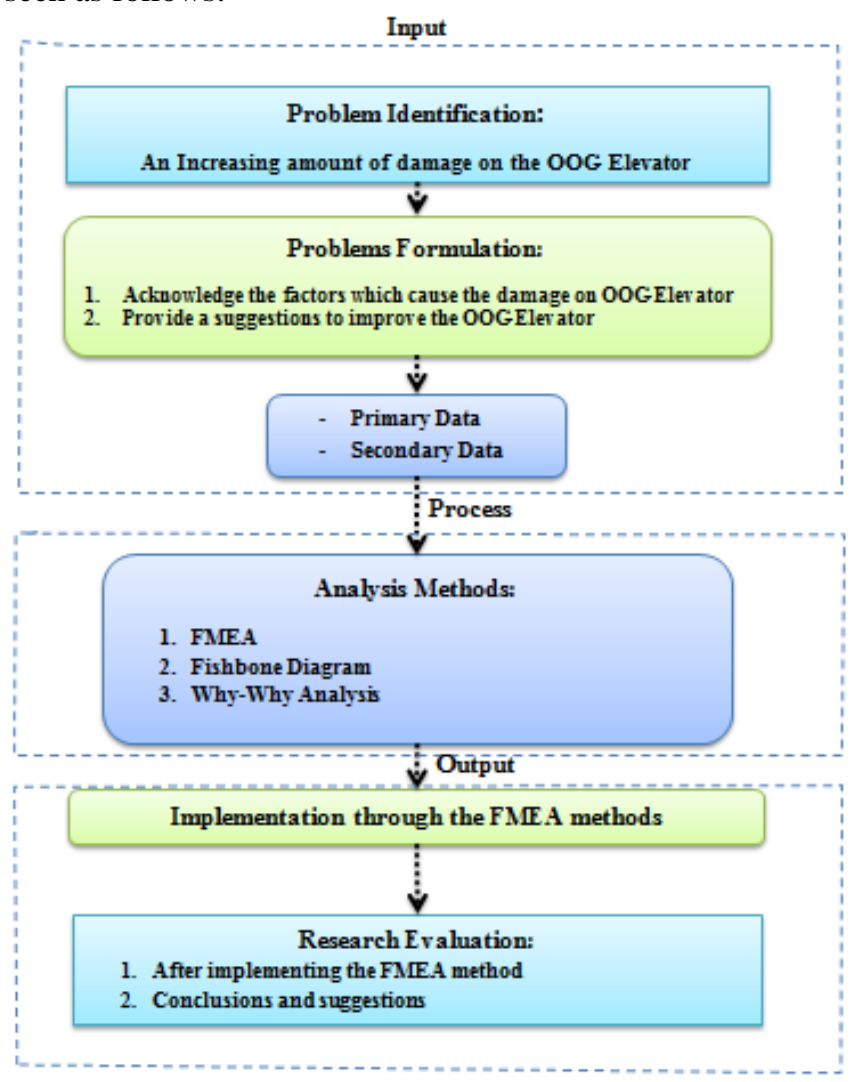

Fig. 1 Theoretical Framework

\section{METHODOLOGY}

The type and design of this research was quantitative with a descriptive design and with included a case study. The independent variable in this research were consists of saferity, occurrence and detection, while the dependent variable is failure mode effect analysis (FMEA).

The research population were all elevators in the domestic terminal area of Soekarno Hatta Airport with a total of 16 elevator units consisting of 2 units of special freight lifts, 4 units of disabled special lifts and 10 units of public lifts. The samples on this research were three elevator units with the highest number of damage, namely: OOG elevators, loading docks elevators and Plaza elevators. The sampling technique used was nonprobability technique which included on purposive sampling type. The data collection method used the combination of two methods, which is primary data collection methods and secondary data. The stages of data processing flows in this research were: 1) Analysis through the level of damage with FMEA value (RPN); 2) Analysis by the fishbone method; and 3) Determined the proposed improvement using the why-why analysis method.

\section{FINDINGS AND DISCUSSION}

\section{A. The Identification of Faulty Elevators}

According to the data from the OOG elevator damage report, it is seen that out of the number of damage 26 times it was found that 10 times of the damage caused by being hit by a trolly, and it was the biggest contributor to damage during 2019.

According to the plaza elevator damage report data, it is known that out of the 8 times from the damage was found, 3 times of the damage was caused by the loose of v-belt door motor and the others were only one damage, so the cause of the damage would be focused on research towards v-belt door motor which is slack.

According to the loading dock elevator damage report data, it is known that out of the 6 times from the damage who was found, 3 of them was caused by being hit by a trolly and it was the biggest contributor to damage during period of 2019.

\section{B. The Calculation through Failure Mode Effect Analysis}

The determination of the saferity value/severity of the damage was obtained directly from the engineering team which handling the problems directly on the field, the saferity scale revealed from the impact which caused by the damage to the unit. According to the monthly report from the engineering team. Elicited from the analysis results, it is known that the ME safety system did not function at all, thus endangering the user/operator to get the highest rating.

The determining of the occurrence value would detect how often the event failure or damage occurs. Based on these analysis results, it is well-known that there have been 10 same failure events in 1 year.

The determination of the detection value would determines how high the level of difficulty to detect the cause of the damage. According to the analysis result, it is known that the cause of the damage is unable to detected to get the highest rating.

The Risk Priority Number (RPN) value is the multiple from the occurrence, saferity and detection values for each failure mode. The highest RPN value means that the component requires immediate treatment if failure mode occurs. Based on the estimation of the Risk Priority Number (RPN), it is known that the highest RPN value in the OOG elevator is damage to the car door roller which is by 200 , the highest RPN value in the plaza elevator is damage to the 
V-belt door motor of 75, the highest RPN value in the loading dock elevator is the damage to the V-belt door motor by 120 .

\section{Cause and Effect Analysis (Fishbone Diagram)}

After using FMEA analysis, it is known that there is 1 component with the highest RPN value caused by the elevator door being hit by a pallet trolly, then it will be done by discover and reveal the causes of the car door being hit by the trolly through the fishbone analysis method.

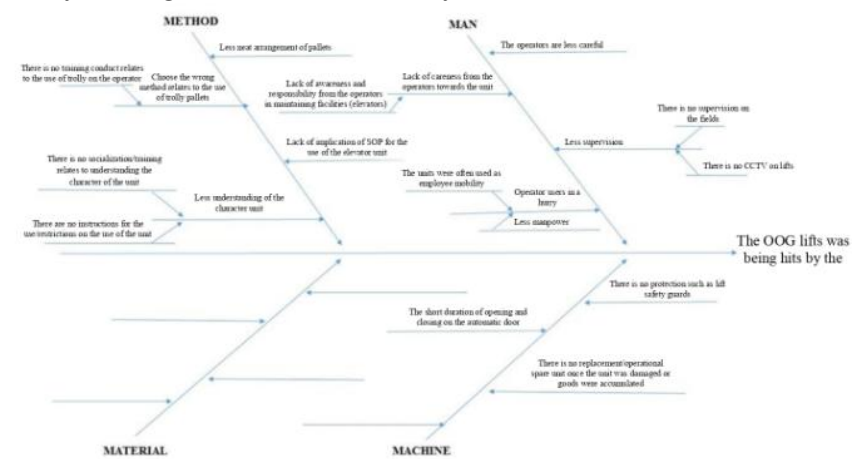

Fig 2. Fishbone Diagram

D. Factors which causing the damage to the elevator door (elevator) which hit by pallet trolly

To find out the factors which caused the door being hit by the trolly, a causal analysis was carried out with parameters: man, method, machine, and material to discover the main cause of this incident so the further improvements were made.

1. Man

a. Operators in a hurry

b. There is no direct field supervisor or indirect supervision via CCTV.

c. Lack of awareness and responsibility for operators in maintaining facilities (elevators).

\section{Method}

a. There is no socialization/training to operators in understanding the characteristics of the unit.

b. The method of using the pallet trolly is wrong.

c. The untidy arrangement of goods on pallets makes it difficult for operators to see ahead when pushing the trolly.

d. Lack of SOP expectations when working using the OOG elevator unit.

\section{Machine}

a. There is no protection/safety gates in front of the elevator door.

b. The duration of opening and closing on the automatic door has less times (30 seconds).

c. There is no spare/replacement unit.

4. Material

There is no material factor which affects the crash of the trolly at the elevator door.

\section{E. Problems Solutions to the cause of Elevator Damage}

The following is an solution which could be given based on the use of the why-why analysis method with direct interviews and discussions to engineering and elevator operators:

\section{Man}

According to the interviews and direct discussions with engineering and elevator operators, solutions that can be given regarding man factors are as follows:

Table 1. Solutions to the Man Factor Problems

\begin{tabular}{|c|c|c|c|c|}
\hline Man & Why l & Why 2 & Why 3 & Corrective Solution \\
\hline \multirow[t]{3}{*}{$\begin{array}{l}\text { The operators is } \\
\text { in hurry }\end{array}$} & $\begin{array}{l}\text { The goods are } \\
\text { overloads }\end{array}$ & $\begin{array}{l}\text { Less } \\
\text { Manpower } \\
\text { (only 2 people } \\
\text { each shift) }\end{array}$ & $\begin{array}{l}\text { Company } \\
\text { efficiency }\end{array}$ & $\begin{array}{l}\text { Need to reschedule } \\
\text { relates to the } \\
\text { manpower issues }\end{array}$ \\
\hline & & Lift queue & $\begin{array}{l}\text { There's still has } \\
\text { an employees } \\
\text { who still used } \\
\text { the lift as for } \\
\text { mobilized thou } \\
\text { they have their } \\
\text { own lift }\end{array}$ & $\begin{array}{l}\text { Need to create the } \\
\text { rules so then the } \\
\text { employees would } \\
\text { keep using their own } \\
\text { lifts and stay away } \\
\text { from the OOG lifts }\end{array}$ \\
\hline & & $\begin{array}{l}\text { There is only } \\
\text { one } \\
\text { lifts/elevator }\end{array}$ & $\begin{array}{l}\text { Company } \\
\text { efficiency }\end{array}$ & $\begin{array}{l}\text { Need to added more } \\
\text { elevators }\end{array}$ \\
\hline \multirow[t]{2}{*}{$\begin{array}{l}\text { Lack of } \\
\text { supervision }\end{array}$} & $\begin{array}{l}\text { There is no } \\
\text { supervision } \\
\text { /field supervisor }\end{array}$ & $\begin{array}{l}\text { Company } \\
\text { efficiency }\end{array}$ & & $\begin{array}{l}\text { Need CCTV on the } \\
\text { field to supervise the } \\
\text { worker }\end{array}$ \\
\hline & $\begin{array}{l}\text { There is no } \\
\text { CCTV on the } \\
\text { field }\end{array}$ & $\begin{array}{l}\text { Company } \\
\text { efficiency }\end{array}$ & & $\begin{array}{l}\text { Need an indirect } \\
\text { supervision through } \\
\text { CCTV }\end{array}$ \\
\hline $\begin{array}{l}\text { Lack of } \\
\text { awareness from } \\
\text { operators } \\
\text { towards units }\end{array}$ & $\begin{array}{l}\text { Operator feel } \\
\text { less responsible } \\
\text { towards the } \\
\text { damage of unit }\end{array}$ & $\begin{array}{l}\text { There is no } \\
\text { supervisor on } \\
\text { the field }\end{array}$ & $\begin{array}{l}\text { Company } \\
\text { efficiency }\end{array}$ & $\begin{array}{l}\text { Need an indirect } \\
\text { supervision through } \\
\text { CCTV }\end{array}$ \\
\hline $\begin{array}{l}\text { The operators } \\
\text { are less careful }\end{array}$ & $\begin{array}{l}\text { There is no field } \\
\text { supervisor }\end{array}$ & $\begin{array}{l}\text { Company } \\
\text { efficiency }\end{array}$ & & $\begin{array}{l}\text { Need to keep in eye } \\
\text { on the field through } \\
\text { CCTV }\end{array}$ \\
\hline
\end{tabular}

2. Method

Elicited from the interviews and direct discussions with engineering team and elevator operators, the solutions that could be given relates to method factors are as follows:

Table 2. Problem Solution for Method Factors

\begin{tabular}{|c|c|c|c|}
\hline Method & Why 1 & Why 2 & Corrective Solution \\
\hline $\begin{array}{l}\text { Less } \\
\text { understanding } \\
\text { about the } \\
\text { characteristic of } \\
\text { unit }\end{array}$ & $\begin{array}{l}\text { There is no } \\
\text { direction or } \\
\text { restriction relates } \\
\text { to the use of units }\end{array}$ & $\begin{array}{l}\text { There is no } \\
\text { training or } \\
\text { socialization } \\
\text { relates to the } \\
\text { knowledge of } \\
\text { units }\end{array}$ & $\begin{array}{l}\text { It is necessary to conduct } \\
\text { the training to operator in } \\
\text { order to give any clue } \\
\text { relates to the use of } \\
\text { elevator units }\end{array}$ \\
\hline $\begin{array}{l}\text { Use wrong } \\
\text { Method of trolly } \\
\text { pallets }\end{array}$ & $\begin{array}{l}\text { There is no } \\
\text { training or } \\
\text { socialization } \\
\text { relates to the use } \\
\text { of trolly pallets on } \\
\text { operators }\end{array}$ & & $\begin{array}{l}\text { It is necessary to conduct } \\
\text { the training to operator } \\
\text { regarding the use of trolly } \\
\text { pallets }\end{array}$ \\
\hline $\begin{array}{l}\text { Untidy } \\
\text { disposition of } \\
\text { pallets }\end{array}$ & $\begin{array}{l}\text { Lack of } \\
\text { awareness and } \\
\text { responsibility } \\
\text { from the } \\
\text { operators to keep } \\
\text { maintaining the } \\
\text { facilities }\end{array}$ & $\begin{array}{l}\text { There is } \\
\text { supervision } \\
\text { the field }\end{array}$ & $\begin{array}{l}\text { There is need to do } \\
\text { indirect supervision } \\
\text { through CCTV }\end{array}$ \\
\hline $\begin{array}{l}\text { Lack of } \\
\text { implementation } \\
\text { of SOPs relates } \\
\text { to the use of } \\
\text { elevator units }\end{array}$ & $\begin{array}{l}\text { There is no } \\
\text { supervision on the } \\
\text { field }\end{array}$ & $\begin{array}{l}\text { Company } \\
\text { efficiency }\end{array}$ & $\begin{array}{l}\text { It is neccesary to put } \\
\text { CCTV to keep in eye on } \\
\text { the field }\end{array}$ \\
\hline
\end{tabular}

3. Machine

Elicited from the direct interviews and discussions with engineering team and elevator operators, the solutions that could be stated regarding machines factors are as follows: 
Table 3. Solutions to the Machines Factor Issues

\begin{tabular}{|c|c|c|c|}
\hline Machine & Why 1 & Why 2 & Corrective Solution \\
\hline $\begin{array}{l}\text { There are no } \\
\text { safety gates on the } \\
\text { lift's door }\end{array}$ & $\begin{array}{l}\text { It was none from } \\
\text { the beginning of } \\
\text { installation }\end{array}$ & $\begin{array}{l}\text { There is no initial } \\
\text { design }\end{array}$ & $\begin{array}{l}\text { It is necessary to add a } \\
\text { safety gate in front of the } \\
\text { door lift }\end{array}$ \\
\hline $\begin{array}{l}\text { The duration of } \\
\text { opening and } \\
\text { closing for the } \\
\text { automatic doors } \\
\text { which are still less } \\
\text { longer (30s) }\end{array}$ & $\begin{array}{l}\text { The lift still uses } \\
\text { standard setting }\end{array}$ & $\begin{array}{l}\text { There is no setting } \\
\text { change request }\end{array}$ & $\begin{array}{l}\text { Need to resetting the } \\
\text { automatic door from } 30 \mathrm{~s} \\
\text { to } 60 \mathrm{~s} \text { so then when } \\
\text { doing maneuver to } \\
\text { entering the trolly would } \\
\text { be slower and not in rush }\end{array}$ \\
\hline $\begin{array}{l}\text { There is no } \\
\text { additional spare to } \\
\text { replace if the } \\
\text { damage occurs or } \\
\text { overloads }\end{array}$ & $\begin{array}{l}\text { There is no initial } \\
\text { design }\end{array}$ & $\begin{array}{l}\text { Company } \\
\text { efficiency }\end{array}$ & $\begin{array}{l}\text { It is necessary to add one } \\
\text { more unit as a spare just } \\
\text { in case the unit is } \\
\text { damaged or overloads }\end{array}$ \\
\hline
\end{tabular}

4. Material

There are no neccesary to repairs because there are no material factors which could affect to the cause of the damage to the door which being hit by the trolly.

\section{CONCLUSION}

\section{A. Conclusion}

The conclusions that could be drawn from this research are as follows:

1. The most dominant factor which caused elevator damage on the OOG elevator door (freight lift)was being hit by a pallet trolly. This was analyzed by the Failure Mode effect analysis (FMEA) method to get the highest RPN value of 200 .

2. The efforts that could be made by the company in order to reduce the amount of damage to the lift which was caused by the door being hit by the trolly are:

a. It is necessary to reschedule by maximizing manpower, so the service would be fulfilled though at busy times.

b. Provide sustainably training related to SOPs, rules for using lifts, socializing the characteristics of lift units, operating lifts and hand pallets, and taking firm action against operators who violate or neglect the lift usage rules.

c. Conduct indirect surveillance by installing CCTV inside and outside the lift.

\section{B. Suggestion}

The suggestions which could be drawn from this research are as follows:

1. The company needs to install a safety gate in front of the lift to avoid the direct collisions on the lift which are caused by operator failure in transporting the goods into the lift. With the safety gate, the operator would not be able to enter the goods which simply arrange and it is not neat or tilted because it will be stuck on the safety gate. Therefore, the trolly could enter the elevator with arrangement of goods which are completely tidy and straight.

2. Adjustments need to be done regarding the opening and closing times of the lift doors. Originally the duration was only 30 seconds, and it needs to be increased to 50 to 60 seconds so the operators will no longer rush to maneuver before entering the elevator. Thus, it would reduce the potential for crashing at the elevator door.

3. There needs to be a prevention and firm action on employees who still use freight lifts as employee mobilization, while the company has provided special lifts for them.

4. There needs to be an increase in terms of routine maintenance as well as routine checking from the engineering team in order to monitor and address issues directly on the field if something goes wrong in the unit.

5. There needs to conduct a weekly briefing/refreshment to the operator in an effort to remind and improve the operator awareness towards the elevator unit.

\section{REFFERENCES}

[1] Adi, K. (2020). Analisa Pengendalian Kualitas Untuk Mengurangi Deffect Pada Produk Primary Gear Spur Dengan Metode DMAIC dan FMEA di Industri Gear. Skripsi. Fakultas Teknik Universitas Mercubuana. Jakarta.

[2] Alamsyah, F. (2015). Analisis Akar Penyebab Masalah Dalam Meningkatkan Overall Equipment Effectiveness pada Mesin Stripping Hipack III dan Unimacth di PT PFI. Jurnal OEE, III, 289-302.

[3] Leitch, R.A. (1983). Pengenalan Sistem Informasi. Yogyakarta: Andi.

[4] Moubray, J. (1997). Reliabiliy Centered Maintenance. Industrial Press Inc: New York.

[5] Murnawan, H., \& Mustofa. (2014). Perencanaan Produktivitas Kerja dari Hasil Evaluasi Produktivitas dengan Metode Fishbone di Perusahaan Percetakan Kemasan PT. X. Jurnal Teknik Industri HEURISTIC, 11(1).

[6] Novyanto, O. (2007, $4^{\text {th }}$ December). Mengenal FMEA (QS: 9000 FMEA Third Edition). Blogspot. http://okasatria.blogspot.com/2007/12/mengenal-fmea-qs-9000-fmea-t hird.html

[7] Nurkertamanda, D., \& Wulandari, F.T. (2012). Analisa Moda dan Efek Kegagalan (Failure Mode and Effects Analysis/FMEA) pada Produk Kursi Lipat Chitose Yamato HAA. J@ti Undip: Jurnal Teknik Industri, 4(1), 49-64. https://doi.org/10.12777/jati.4.1.49-64

[8] Pratama, B.G., \& Rahardjo, B. (2020). Analisis dan Usulan Perbaikan untuk Defect Pemasangan Lift. Jurnal Titra, 8(1), 89-96.

[9] Ridwansyah, M., Nusraningrum, D., \& Sutawijaya, A.H. (2019). Analisis Overall Equipment Effectiveness Untuk Mengendalikan Six Big Losses Pada Mesin Pembuatan Nugget. Publikasi Mercu Buana. Universitas Mercu Buana. Jakarta.

[10] Rusmiati, E. (2012). Penerapan Fuzzy Failure Mode and Effect Analysis (Fuzzy FMEA) Dalam Mengidentifikasi Kegagalan Pada Proses Produksi di PT. Daesol Indonesia. Jurnal Teknologi dan Manajemen, 10(2)

[11] Susman, H. (2012). Lift Elevator \& Escalator. ANZDOC. https://adoc.pub/lift-elevator-escalator.html 